BIBECHANA

A Multidisciplinary Journal of Science, Technology and Mathematics

ISSN 2091-0762 (online)

Journal homepage: http://nepjol.info/index.php/BIBICHANA

\title{
Household solid waste production and its management in Biratnagar sub-metropolitan city
}

\author{
Ram Chandra Adhikari* \\ Department of Zoology, Tribhuvan University, Central Campus of Science and Technology, Hattisar, \\ Dharan \\ Article history: Received 2 October 2010; Revised 5 November 2010; Accepted 10 November 2010
}

\begin{abstract}
The study was conducted from March to May month of 2010 A D in Biratnagar regarding the waste production and management. Total amount of waste produced was recorded about 46.877 tonnes per day. The highest amount was from urban rural area (44.637 tonnes) and the lowest was from main bazaar (0.689 tonnes). About 69.19 percent households collect waste separately . 45.90 percent households dump degradable waste. 80 percentages of all households sell non degradable waste and only 33.67 percentage people of this town have scientific knowledge of waste management.
\end{abstract}

\section{Keywords: Solid waste; Biodegradable waste; Improper settlements}

\section{Introduction}

Biratnagar sub-metropolitan city $\left(26^{\circ} 28^{\prime} \mathrm{N}, 86^{\circ} 19^{\prime} \mathrm{E}\right.$ and $72 \mathrm{~m}$ altitude $)$ is one of four sub- metropolitan cities of Nepal lying in Koshi zone, Morang district . Taking the position as second largest town it locates with the embanked by Singia river in east and Keshlia in west. It enjoys on sub-tropical and monsoon type of climate. This town covers an area about 59.9 square kilometers. A total of 26,699 households and 1, 80,138 people reside in this town. Due to availability of facilities belonging to education, healthcare, employment etc. a lot people are migrating to this town every year. Improper settlements, rapidly growing population, industrialization and lack of sufficient awareness result over production of solid waste and that create many problems. This town has been facing growing solid waste problems.

Any unwanted and discarded materials from residential, commercial, industrial, mining and agricultural activities that cause environmental problems may termed as solid waste. On the other words solid waste can be defined as those wastes which have been rejected for further use and can neither be transported by water into streams nor readily escape into atmosphere . According to Rao [1] the waste arising from human and animal actives that normally solid and described as useless or unwanted. Solid waste is a byproduct of human activities which tends to increase with rapid urbanization, improved living standards and changing consumption patterns.

\footnotetext{
* Corresponding author: Ram Chandra Adhikari, Department of Zoology, Tribhuvan university,

Central campus of Science and Technology, Hattisar, Dharan Email: ramchandra.adhikari@gmail.com
} 
Management of increasing amounts of solid waste has become a major challenge in many cities in developing countries. The amount of waste generated from every person is increasing day per day as a result of social, economical and technological changes. According to WHO [2], it varies from 0.2 to $3 \mathrm{~kg}$ per person per day. UNICEF [3] reported that waste production depends on income of people. People with per capita income below $360 \mathrm{US}$ dollar produce about $0.5 \mathrm{~kg}$ solid waste. Similarly those with per capita income 360 to 3500 dollar produce $1.5 \mathrm{~kg}$ and income above 3500 dollar produce up to $4 \mathrm{~kg}$ of solid waste per day.

On average 58 municipalities in the country are spending about 13 percent of their total budget on waste management related activities but in most cases this amount is not being spent in an efficient manner [4]. According to CBS 1997 [5] only 17 percent of urban households have their waste collected by waste collectors. Furthermore, in low-income households, indicated by houses having no toilets, only 2 percent of the households have their waste collected. Open waste piles are a common site and the work of municipalities is often limited to sweeping the streets and dumping the waste in the nearest river or vacant land.

Solid waste can be classified into two categories. They are bio degradable waste and non degradable waste. Papers, garbage, dead bodies and compost -able waste are the examples of degradable solid waste and plastics, metals, ceramics etc. are non degradable ones. The waste should be managed properly but in the case of Biratnagar there is not suitable dumping site or sanitary landfill site. So problems on the management of solid waste have been rising. Waste management comprises of purposeful and systematic control of the generation, storage, collection, transportation, separation, processing, recycling, recovery and disposal of waste [6].

\section{Objectives}

The main objectives of present study were:

-To measure the total quantity of waste production

-To study management practice of household waste

\section{Materials and methodology}

The following important materials, tools or equipments were used for designing experiment scientifically.

The materials used in the research are as following :collecting drums, spring balance, shovel, thermometer, gloves, field book, forceps, mask, questionnaires, calculator, camera, tongs, plastic bags, spade etc.

Firstly Biratnagar town was divided into three areas namely Main-bazaar ( Ward number 8,9,10 and 14), Semi-urban (3,4,12 and 13) and Urban-rural (1,2,5,6,7,11,15,16,17,18,19,20,21 and 22 ). It was done according to municipality profile. After finding total number of households, 10 percent (about 300 households) of total number was taken for the study. Special attention was given to include the households of all toles. Fifteen individuals were trained as observers and used in the field with researcher. From each sample house, waste production was weighed with the help of spring balance twice a week and amount of average production was calculated. During the study period the waste management methods were also observed. By giving a questionnaire to fill up to the public and direct observation of existing management practice was studied. The period of study was three months from March to May 2010. 


\section{Result and discussion}

\subsection{Waste production}

The average of solid waste generation from urban-rural region is tabulated in the table 1 .

Table 1

\begin{tabular}{|c|c|c|c|}
\hline S.N. & Month & Types of waste & $\begin{array}{c}\text { Average daily } \\
\text { production ( in kg) }\end{array}$ \\
\hline 1 & March & $\begin{array}{c}\text { Bio degredable + Non } \\
\text { degrdable+Mixed }\end{array}$ & $\begin{array}{c}17540+6440+20000=4398 \\
0\end{array}$ \\
\hline 2 & April & $\begin{array}{c}\text { Bio degredable+Non } \\
\text { degredable+ Mixed }\end{array}$ & $\begin{array}{c}18702+7845+21033=4758 \\
3\end{array}$ \\
\hline 3 & May & $\begin{array}{c}\text { Bio degredable+ Non degredable } \\
+ \text { Mixed }\end{array}$ & $\begin{array}{c}16980+5488+19882=4235 \\
0\end{array}$ \\
\hline Average & & & $\mathbf{4 4 6 3 7 . 6 6 7}$ \\
\hline
\end{tabular}

From the above table in March biodegradable waste was produced $17540 \mathrm{~kg}$, non degradable waste $6440 \mathrm{~kg}$ and non-separated was $20000 \mathrm{~kg}$. Similarly $18702 \mathrm{~kg}$ of biodegradable,7845 kg of non degradable and 21033 mixed type of waste was produced and total amount was $47583 \mathrm{~kg}$ in April. In the case of May month biodegradable $16980 \mathrm{~kg}$, non degradable $5488 \mathrm{~kg}$ mixed 19882 $\mathrm{kg}$ and total $42350 \mathrm{~kg}$ was generated per day. The sum of total waste generation was found to be $44637.667 \mathrm{~kg}$.

The average of solid waste solid waste generation from semi urban region is tabulated in table 2 .

Table 2

\begin{tabular}{|c|c|c|c|}
\hline S.N. & Month & Types of waste & $\begin{array}{l}\text { Average daily } \\
\text { production (in } \mathrm{kg} \text { ) }\end{array}$ \\
\hline 1 & March & Bio degredable + Non degrdable+Mixed & $540+192+732=1464$ \\
\hline 2 & April & $\begin{array}{l}\text { Bio degredable+Non degredable+ } \\
\text { Mixed }\end{array}$ & $555+243+679=1477$ \\
\hline 3 & May & $\begin{array}{l}\text { Bio degredable+ Non degredable } \\
+ \text { Mixed }\end{array}$ & $675+272+765=1712$ \\
\hline Average & & & 1551 \\
\hline
\end{tabular}

Above table shows that from semi urban area in March $540 \mathrm{~kg}$ of bio degradable waste, $192 \mathrm{~kg}$ of non degradable and $732 \mathrm{~kg}$ of non-separated waste was excreted out per day. The total amount of solid waste produced was about $1464 \mathrm{~kg}$ daily. In the month of April $555 \mathrm{~kg}$ biodegradable, 243 $\mathrm{kg}$ non degradable, $679 \mathrm{~kg}$ mixed and total $1477 \mathrm{~kg}$ of non separated waste was found to come out from the houses. $675 \mathrm{~kg}$ bio degradable, $272 \mathrm{~kg}$ non degradable and $765 \mathrm{~kg}$ mixed waste and a total of $1712 \mathrm{~kg}$ was excreted out daily. In average $1551 \mathrm{~kg}$ waste was found to be generated everyday from this area.

The average of solid waste solid waste generation from main bazaar region is furnished in table 3. 
Table 3

\begin{tabular}{|c|c|c|c|}
\hline S.N. & Month & Types of waste & $\begin{array}{c}\text { Average daily } \\
\text { production ( in kg) }\end{array}$ \\
\hline 1 & March & $\begin{array}{c}\text { Bio degredable + Non } \\
\text { degrdable+Mixed }\end{array}$ & $240+100+331=671$ \\
\hline 2 & April & $\begin{array}{c}\text { Bio degredable+Non degredable+ } \\
\text { Mixed }\end{array}$ & $385+123+342=850$ \\
\hline 3 & May & $\begin{array}{c}\text { Bio degredable+ Non degredable } \\
\text { +Mixed }\end{array}$ & $\begin{array}{c}299+112+235=546 \\
\text { Average }\end{array}$ \\
\hline
\end{tabular}

Above table tells that from main bazaar area in March $240 \mathrm{~kg}$ of bio degradable waste, $100 \mathrm{~kg}$ of non degradable and $331 \mathrm{~kg}$ of non-separated waste was excreted out per day. The total amount is about $671 \mathrm{~kg}$ daily. In the month of April $385 \mathrm{~kg}$ biodegradable, $123 \mathrm{~kg}$, non degradable $342 \mathrm{~kg}$ mixed and total $850 \mathrm{~kg}$ of waste comes out from the houses. $299 \mathrm{~kg}$ biodegradable, $112 \mathrm{~kg}$ non degradable and $546 \mathrm{~kg}$ mixed waste and a total of $546 \mathrm{~kg}$ was excreted out daily. $689 \mathrm{~kg}$ was the average daily waste production.

Total waste generation from whole Biratnagar sub-metropolitan city is displayed in table 4 .

Table 4

\begin{tabular}{|c|c|c|}
\hline S. N. & Area & waste production (in kg per day ) \\
\hline 1 & Urban rural & 44637.667 \\
\hline 2 & Semi urban & 1551 \\
\hline 3 & Main bazaar & 689 \\
\hline & Total & $\mathbf{4 6 8 7 7 . 6 6 7}$ \\
\hline
\end{tabular}

According to the above table total amount of waste production from this town was found to be about $466877.667 \mathrm{~kg}$ or 46.6877 metric tonnes per day. It was made by $44637.667 \mathrm{~kg}$ from urban rural as maximum and $689 \mathrm{~kg}$ from main bazaar as minimum.

\subsection{Waste management practice}

During the study the following practices were observed in whole sub-metropolitan city. Data were taken region wise and total of the town is presented here in all the topics.

- 69.19 percent households collect biodegradable and non degradable waste separately.

- About 45.90 percent households dump degradable waste in the pit in house compound. Rest of them throws the solid waste randomly.

- 80 percentages of all households sell non degradable waste.

- Only 33.67 percentage people have scientific knowledge of waste management.

\section{Conclusion}

Biratnagar sub-metropolitan city is in trouble of solid waste problem. A huge amount of solid waste (46.687 tonnes) has daily been produced. There are not sanitary landfill site, proper 
awareness and cultural practices of waste management. Some people (69.19 percent) collect waste separately but large population throws them everywhere. About 80 percentages of households sell plastics and metal born waste as they don't have sufficient practice of reuse. According to the study 33.67 percentage people know the method of waste management. This town is seeking for a good guideline, enough budget, proper awareness, skilled human resource etc. for waste management.

\section{Acknowledgements}

The author is thankful to Sagaramatha Community Development Center (SCDC) for financial support to this study. The author is also grateful to Dr. Damodar Thapa for the valuable suggestions and inspiration to conduct the project.

\section{References}

[1] C.S. Rao, Study of solid waste management for environment pollution control Engineering, Wiley Eastern limited, Delhi, (1985).

[2] WHO, solid waste disposal and control, Public health papers 38, Geneva , (1971).

[3] UNICEF, The state of children and environment, New York, (1990).

[4] SWMRMC, A Diagnostic Report on State of Solid Waste Management in Municipalities of Nepal, Solid Waste Management and Resource Mobilization Centre, Lalitpur, (2004).

[5] CBS, Urban Population Survey 1996, Central Bureau of Statistics, His Majesty's Government of Nepal, Kathmandu, (1997).

[6] S.S. Dara, A Text book of environmental chemistry and pollution control, S. chand and company Ltd, New Delhi, ( 1998) .

\section{Further Readings}

[7] A.K Deo, Environmental chemistry, New age international limited, New Delhi, (2001).

[8] R.C. Adhikari, Study of solid waste management, A thesis submitted to P.G. Campus Biratnagar,(2OO5) . 